\title{
Combining school with part-time work: Empirical findings from Germany
}

\author{
Claus Tully
}

Free University of Berlin / Free University of Bozen - Bolzano

tully@zedat.fu-berlin.de

\section{Benjamin Fillisch}

University of Education Freiburg

benjamin.fillisch@ph-freiburg.de

\section{Eric van Santen}

German Youth Institute e. V. santen@dji.de

\begin{abstract}
This article begins by outlining the current state of research into the issue of part-time work taken by secondary school students. The findings for Germany are based on a childhood and youth survey (AID:A). The survey population comprises school students aged 13 to $17(\mathrm{~N}=2,763)$. As young people's primary motive for taking a job while at school is to earn income, their financial position with and without jobs is included in the study.

About one third of the students have jobs. Thus young people operate simultaneously in parallel worlds (school, family, peer group, youth culture, work environment). The proportion of school students with jobs increases markedly with age. No detriment to voluntary commitments or school achievement results from having a job. Students from lower-income households take jobs more frequently, but earn less income from them than do students from higher-income households. In broad terms, part-time jobs provide appreciable additional freedom of manoeuvre in young people's budgets. This in turn facilitates participation in consumption-based youth culture. The article ends with a reflection on research deficits and a discussion of anticipated developments in the part-time labour market.
\end{abstract}

Keywords: School performance; budget; students; job; youth; economic conditions. 
Resumen. Combinar la escuela con trabajo a tiempo parcial. Resultados empíricos de Alemania

En el presente artículo se pretende esbozar el estado actual de las investigaciones sobre el empleo a tiempo parcial de estudiantes escolares. Los datos con respecto a Alemania se derivan de la encuesta AID:A con una población de estudiantes de entre 13 y 17 años $(\mathrm{N}=2,763)$. Puesto que el motivo principal por el que los jóvenes deciden trabajar mientras estudian es ganar dinero, se han incluido en este estudio datos sobre su situación económica con y sin trabajo.

Aproximadamente un tercio de los estudiantes trabajan. Éstos intervienen simultáneamente en distintos mundos (la escuela, la familia, los grupos de iguales, la cultura juvenil, el ambiente laboral). La proporción de jóvenes escolares que trabajan aumenta notablemente con la edad. Este hecho no afecta a sus compromisos voluntarios ni al rendimiento escolar. Los alumnos de familias con rentas más bajas trabajan con más frecuencia, pero obtienen menos ingresos que los alumnos de familias de rentas más altas. En términos generales, los empleos a tiempo parcial permiten a los jóvenes tener un mayor margen de maniobra en su presupuesto. Esto a su vez facilita su participación en una cultura juvenil basada en el consumo. Este artículo finaliza con una reflexión sobre los déficits en la investigación y lanza un debate sobre el desarrollo previsto en el mercado de trabajo a tiempo parcial.

Palabras clave: rendimiento escolar; presupuesto; estudiantes; trabajo; jóvenes; condiciones económicas.

\section{Summary}

1. Part-time paid work as a component in the everyday life of young people

2. Data basis and methodology

3. School student part-time job uptake in Germany: Empirical findings
4. Commonalities and Differences: the position in Germany and in the other countries

5. Conclusion: Job and School

- Living in Parallel Worlds

References

Appendix

\section{Part-time paid work as a component in the everyday life of young people}

Most young people attend school and are also engaged in coping with specific developmental issues (gender roles, building relationships, achieving independence vis-à-vis parents, partner relations, development of political and moral competences). Importance is attached at this age to individual positioning, both in the peer group and in society at large. Income from employment is delayed for young people so that qualifications can be gained (Luhmann, 2004). This is why youth research in Germany refers to the youth phase as a moratorium. In English-speaking countries it is more usual to view youth and school attendance as a transition period (Eckersley, 1992; Mortimer and Larson, 2002; Furlong et al., 2011). In these publications, issues examined in 
relation to youth include the peer-group, youth culture, extension of the youth phase (e.g. Tanner and Arnett, 2009), and the transition from the education system to the employment system (Tully et al., 2008).

Adoption in successive stages of a society-defined adult role (school-leaving qualifications, autonomy vis-à-vis the family of origin, assumption of responsibility, own income, etc.) is a relatively lengthy process in all modern societies. This prolonged youth status quo is characterised by a pattern of functioning in parallel worlds (school, social networks, everyday cultures, involvement in sport and leisure activities). The perception of the wide diversity of options afforded by modern life ${ }^{1}$ leads to (parallel) slotting into different life spheres. The everyday life of young people is characterised by economic dependence. Youth status is subsidised status. Up until the early 1960s, youth were never significantly economised or commercialised. Today, by contrast, many everyday activities take disposable cash resources for granted. Part-time work can be understood as an attempt to resolve the incompatibility between economically dependent status and commercialised everyday life.

\subsection{Functioning in the parallel worlds of job and school}

By taking part-time jobs, young people gain real-life new experience beyond school, family, peers, and the media. They establish contacts in the world of work, cooperate in the workplace with people outside their age group, get used to trading time against money, take on responsibility, and achieve recognition for what they do. In addition to financial reward, a job provides social gratification. Work accomplished earns young people recognition which is fundamentally different from that routinely accorded at school (standard pattern: assessment, grade award). Experience over time in the work environment may be expected to deliver unplanned learning spin-off in terms of acquired 'soft skills' (teamwork, cooperation, punctuality, reliability, shouldering of responsibility, and development of situational coping strategies).

Reserving our own study findings for presentation in the third section of this paper, we turn now to presenting some findings reported in Englishlanguage publications, topics including the motivation for part-time work while still at school, and the combination of job and other leisure-time activities. Other issues discussed are regional and gender-specific differences, types of activity, and the effect of having a job on individual school achievement. In general, there are relatively few available findings on jobs taken by school students (see Frederiksen, 1999 for Denmark, Patton and Smith, 2010 for Australia, Howieson et al., 2012a and Payne, 2001 for the UK, The Bureau of Labor Statistics [BLS], 2004, 2005 for the US, and Beicht and Krewerth,

1. On the continued search in a world of expanding options, see Tully, 2008: 481. The dualisms of developed modernisation that are relevant to young people's lives include, for instance, keeping options open vs. commitment, risk vs. security, and formalisation vs. informalisation. 
2010; Tully, 2004b; Tully and Wahler, 1993 and Shell Deutschland Holding, 1992, 2002, 2006, 2010 for Germany)

\subsection{Commonalities and differences: School students' jobs in the US, Australia, and Europe}

Differences in research design between the available studies on part-time work taken by secondary school students indicate significant differences in methodology - notably with regard to the age groups surveyed and to the method of recording the activity. When one study enquires as to how many young people are 'currently' carrying on a side activity (as in Frederiksen, 1999), and another as to 'how many did this in the last school year' (as in BLS 2004; 2005), the results are not strictly comparable. Other studies focus on accumulated experience of employment and from that draw inferences with regard to part-time jobs (e.g. Howieson et al., 2012a). Variation in the extent of side activities is thus in part attributable purely to the survey method chosen.

\section{a) Frequency of recourse to jobs}

For the US, over half of high school students (57\%) are reported to have jobs already at the age of 14 (BLS, 2004, 2005). The BLS longitudinal study records the number of students who have worked at least once during the most recent school year. As in other surveys, the percentage of young people with part-time jobs increases with age. Where just under two-thirds (64\%) have part-time jobs at 15 years of age, the proportion for the final school year (ages 17 and 18) increases to three-quarters (BLS, 2004: 11).

These percentages reported for the US are higher than those for other nations. The proportion of children and young people in Denmark with part-time jobs is comparatively high, yet lower than the corresponding figures reported for the US. In Denmark, $43 \%$ of 14 -year-olds have work. By the ages 15 to 17 , more than half of them have begun to bolster their pocket money with jobs (Frederiksen, 1999: 105). In the UK, the survey investigated how many had recently had a job and returned a figure of slightly over $40 \%$ for 16- and 17-year-olds; a figure that rose for the next school year (i.e. 17- and 18-year-olds) to 59\% (Payne, 2001: 13, 22). The data provision for Australia is relatively sparse, but suffices to show clear variations according to what question is asked. One study concluded that $34 \%$ of young people aged 15 to 19 have jobs (Patton and Smith, 2010: 54). This figure is comparable with results from Germany. According to a different study, $56 \%$ of young people aged 12 to 16 had had jobs during the preceding year (NSW Commission for Children and Young People, 2005: 15). This study also showed the typical increase in job incidence with age $(51 \%$ at age 13 vs. $76 \%$ at age 16$)$. According to Tully (2004a: 58), roughly a third of all young people in Germany have regular work from 9th grade on (i.e. from about age 14). The 2010 Shell Youth Study's findings report that, among school students, $15 \%$ of the 12 -to14 age group and 33\% of the 15-17 age group have work as well as attending 
school and so possess a supplementary income source and that young people from the upper and middle socio-economic classes are more likely to have jobs while still at school than those from the lower classes (39/41\% vs. 20\%) (Leven et al., 2010: 86-87).

In both the US and Denmark, young males and young females are equally likely to have jobs (Frederiksen, 1999: 105; BLS, 2004). In Britain and Australia, by contrast, more girls have a part-time job than boys (Howieson et al., 2006: 115; Payne, 2001: 13; NSW Commission for Children and Young People, 2005: 16).

In spite of the clear differences in survey methodology, it has been established that the taking of jobs at school age is substantially more widespread in North America than in other Western welfare states. Internationally, both the proportion of young people holding such jobs and the amount of time devoted to them increase with age. In most of these countries, most of these young people work for between one and ten hours per week. Only a quarter to a third work for as long as ten to 15 hours per week. And only a tiny percentage of the young people devote more than 20 hours per week to their job (Frederiksen, 1999: 105; Howieson et al., 2006: 74; Payne, 2001: 15, 23; Patton and Smith, 2010: 55). Here too an exception must be noted in the case of the US, for young people there spend more hours on out-of-school jobs than their counterparts in other countries (BLS, 2005). For Germany, additional data are available with regard to the extent of outside job take-up by Auszubildende (registered trainees: standard abbreviation Azubis) in the context of the dual system distinctive to Germany. ${ }^{2}$ Azubis work about 9.2 hours in addition to their full-time training of nearly 40 hours per week divided between the workplace and the vocational school (Beicht and Krewerth, 2010). ${ }^{3}$

British and American studies additionally indicate the distribution of jobs in terms of different ethnic groups. In this regard, differences emerge both in the US and in Britain and Australia (BLS, 2005; Payne, 2001: 35; NSW Commission for Children and Young People, 2005: 19). It appears that young 'non-Hispanic' white people may take jobs more often than others. In the US, $47 \%$ of white school students of non-Hispanic origin work in their first high school year, compared with one-third of black non-Hispanics and one-third of Hispanics/Latinos. In the final high school year, the numbers rise for all three groups, but once again there are appreciably more white non-Hispanics (BLS, 2005). In Britain, 48\% of white 9th-year school students have jobs, which is more than the corresponding constituencies of black students (36\%), or of students of Indian (24\%) or other origins (30\%) (Payne, 2001: 36). The author puts forward two possible explanations for this: either non-white young

2. Training is given at the workplace and runs parallel with conventional school attendance (approx. one day per week). The system is based on career templates designed jointly by employers, trade unions, and state educational institutions.

3. $27 \%$ of Azubis take a part-time job in their second year of training (Beicht and Krewert, 2010: 9). 
people have less desire to work (and/or focus more on academic education), or their desire for work is no less than that of the other group but there is discrimination against them on the part of employers.

\section{b) Job motivation}

The available studies consistently show cash income to be the principal incentive for taking a job (Abhayaratna et al., 2008: 83; Frederiksen, 1999: 109; Howieson et al., 2006: 57). In all but a few cases, young people work in order to strengthen their finances. Enhancement of the family's income is the exception rather than the rule. Young people want to press on towards full financial severance from the family of origin, funding their consumption themselves. Many of them already fund such essentials in life as transport, clothing, and mobile phone communication by combining their earnings with pocket money from parents (Tully et al., 2011: 14). This indicates that a prime concern is for severance and autonomy, and independence is accordingly often cited as the second most frequent motive (Howieson et al., 2006: 57; Abhayaratna et al., 2008: 83). However, independence also means the acquisition of new contacts and new sets of relationships, with overall less time available for spending in the parental family context. Additional money from job pay represents the opportunity to go out reasonably frequently and stay away more often from the parental household. When consumption is financed with money one has earned personally, the obligation to give account to parents for one's expenditure is reduced. This autonomy matters to young people.

The idea of preparation for a future career is a less widespread motive for taking a job while still at school. Only a small percentage of young people declare the intention of acquiring experience in a professional field in which they intend to work later (Abhayaratna et al., 2008: 93; Howieson et al., 2006: 57). Subjectively, career commencement still seems to lie in the remote future, so that only a small number of young people engage in part-time work with the intention of acquiring competences that will be useful in their later career (Abhayaratna et al., 2008: 93; Patton and Smith, 2010: 56; Howieson et al., 2006: 57).

\section{c) Types of job}

There is widespread consensus among secondary sources internationally that the jobs taken by school students differ according to gender (Frederiksen, 1999: 105; Howieson et al., 2006: 70; BLS, 2004). Tasks that have always tended to be associated with feminine skills, such as babysitting, are still undertaken mainly by girls. Boys more commonly work as farmhands or in factories and workshops. Delivery services are another job that tends to be taken up mostly by boys (Howieson et al., 2012a: 325). Even in businesses that employ both sexes, males and females will not necessarily do the same type of work. In retail, for example, girls will be more apt to work at checkouts and in direct customer service, while boys work more as store-hands and shelf-stackers (Frederiksen, 1999: 105). 
Only among the oldest generation of young people is there significant further differentiation of job type (Windau and Meyer, 2005: 11). The most important additions at that stage are in the hospitality trade and in retail.

\section{d) Part-time working and school attainment}

Research on the relationship between part-time working and school attainment was characterised by conflicting findings for a long period of time. While some studies supported the assumption that part-time work would lead to lower marks and increased problem behaviour at school (Lee and Ju, 2010: 3228; McCoy and Smyth, 2007: 237), others actually found that young people who had jobs were achieving improved results at school (Tully, 2004b: 423). The polarity was eventually resolved after duration of employment had been additionally factored into the calculations. This broader view brought the insight that where young people devote only a small amount of their time to their out-of-school job this has no impact on school attainment. Only beyond a particular threshold does the issue become critical. Here the studies found that the length of time per week that young people can spend on their job without negative consequences increases with age (Payne, 2001: 73; Staff et al., 2010: 195). From age 15 onwards, the threshold figure is approximately 15 to 20 hours per week; appreciably above the actual mean working hours of young people.

The differing results have given rise to various conjectures. One argument for poorer performance at school is that those with jobs have less time to devote to study and that if the job is too demanding, the student will find it difficult to concentrate on homework. With the introduction of more intensive educational regimes, another theory contends: there is little scope for additional activities to round out the normal school day. An opposing argument, in turn, maintains that students handling a job alongside schoolwork have become more skilled at allocating their time and in general conduct themselves more responsibly; accordingly, it is claimed, they actually learn more effectively and achieve better academic outcomes than young people who have no outside job (e.g. Payne, 2001: 65). A neutral position is that jobs are not per se harmful to academic attainment. When working hours are relatively few, there is no difference from students who do not have jobs. Above a given time commitment, however, there is an appreciable deterioration vis-à-vis non-working students. This particular hypothesis is referred to as the "threshold model" (e.g. Marsh and Kleitman, 2005: 334).

The fact is that scarcely any evidence exists of a causal relationship between job activity and school attainment. Young people do not pursue a resolve to learn efficiently at all times. Only if such were the case could out-of-school jobs be seen as a loss of learning time. Presumably, young people learn things from their part-time job that will have bearing on their future lives (increased insight into employed work routine, experience in coping with work-related pressures). It is also reasonable to assume that manifestly low-achieving young people will tend not to be taken on for various specific jobs. It does not con- 
flict with that to argue that precisely these young people with weak academic attainment might well find the work environment more congenial than school and accordingly invest the best of their energies in their out-of-school job (Entwisle et al., 1999: 384).

Alongside these empirical findings, a number of frequently reiterated assumptions remain current in the international research literature even though they are proving hard to substantiate empirically. These relate to two topics in particular: first, the usefulness of contacts in the world of work, and second, the function of students' part-time jobs in relation to the process by which young people gain personal autonomy. According to Tully (2004b: 421-423), a job at this stage always has the additional function of an informal learning arena located outside the formal education system and presenting supplementary learning opportunities. Fulfilment of the duties of a part-time job can be seen as a step towards learning to accept responsibility - given that the young people concerned must submit to the prevailing constraints on employees (punctuality, trading of leisure time against money, cooperation with individuals not chosen by oneself, cooperation with people of different generations, etc.). In schools, the work environment is described second hand, but in the environments provided by part-time jobs it is possible to try out an envisaged future career. Students are enabled to test in practice to what extent the work experience of their aspirations corresponds to the workplace reality. They learn what competences they will be expected to have, and are in many cases prepared to upgrade them as a way of assisting career entry at a later stage. Part-time work is not necessarily enjoyable. Jobs are not judged by the same criteria as leisure activities or peer-related activities. They operate in parallel worlds requiring principles of action different from those customary at school.

The young person's overall life project - the attaining of personal independence - subsumes severance from the family, the development of selfbelief, identity work, and positioning oneself in society. Part-time jobs can help develop social and problem-solving competences (e.g. teamwork, cooperation, punctuality, reliability, acceptance of responsibility, and situational coping strategies) (e.g. Tully, 2004b: 413). Over time, the young person also acquires practical and organisational skills, self-regulatory routines, a more mature sense of responsibility, and adult perspectives (Marsh and Kleitman, 2005: 334). Young people in part-time work while at school have to take on tasks requiring the soft skills on which today's economy places a premium (Howieson et al., 2012b: 429). Additionally, the planning of one's future career will benefit from drawing on first-hand experience. It is only through direct personal contact and real-life work that one can learn what it is to be an employee, personally and by observation of others (Wray-Lake et al., 2011: 1113)

\section{Data basis and methodology}

The findings shown below are based on evaluation of the 2009 AID:A-Survey "Aufwachsen in Deutschland: Alltagswelten" (Growing up in Germany: 
Everyday Worlds) conducted by the German Youth Institute. AID:A uses a repeated cross-sectional design based on random sampling of individuals from all age groups in Germany from zero to 55 years of age, with fresh samples being used in every survey wave. The survey of 25,337 individuals took the form of a computer-assisted telephone interview (Alt et al., 2011). Children aged nine and over were interviewed first hand. Household data (e.g. income details, parents' education) in the case of minors were obtained through a competent third party, usually the mother.

Data evaluation drawn on in the present paper is confined to those aged 13-17 years attending school $(\mathrm{N}=2,763)$. This category includes many individuals with money at their disposal, but only limited powers of contract. ${ }^{4}$ The actual case numbers are cited in the tables.

In covering certain aspects of the subject of side jobs and pocket money, the authors additionally drew on data from the supplementary "Jugend" youth questionnaire devised by the Socio-Economic Panel (Frick et al., 2008). This questionnaire has been issued since 2000 to any individuals in the randomly sampled households who reach their 17th birthday during the survey year.

The findings of German research studies on the uptake of part-time jobs reveal clear differences. The reason lies in the different types of question used in the respective surveys. For instance, in the Shell study of 2010 the formulation of the part-time work question was: [translated] "In your spare time, do you do paid work?” In the DJI AID:A survey, respondents' involvement or non-involvement in such work was inferred from the questions "Roughly how much spending money do you have each month?", "Where does that money come from?", and the reply category "Cash I earned myself". The Socio-Economic Panel Survey (German acronym SOEP) asks: "Are you earning money already by regular/occasional work?" The provided reply category "Do you earn the money by taking jobs (as a side activity)?" is used to indicate whether the individual has a job.

The results are presented below, initially in descriptive mode referring to socio-demographic characteristics of the school students and of the households to which they belong. Subsequently these characteristics are checked statistically by means of a multivariate analysis and their effect is scrutinised.

\section{School student part-time job uptake in Germany: Empirical findings}

Although young people of today's generation are choosing to postpone continuous earnings status, a proportion of school students have jobs providing temporary income. The results of our analysis of SOEP data indicate whether recent years have seen an increase or decrease in the proportion of 17-year-

4. Once young people have (at 18) attained the age of majority, their situation is fundamentally changed in that they are then considered to have unrestricted powers of contract. Survey results for minors are only partly comparable with those for young adults (i.e. 18 and above). 
Figure 1. Proportion of 17-year-old school students with jobs by calendar year (in \%)

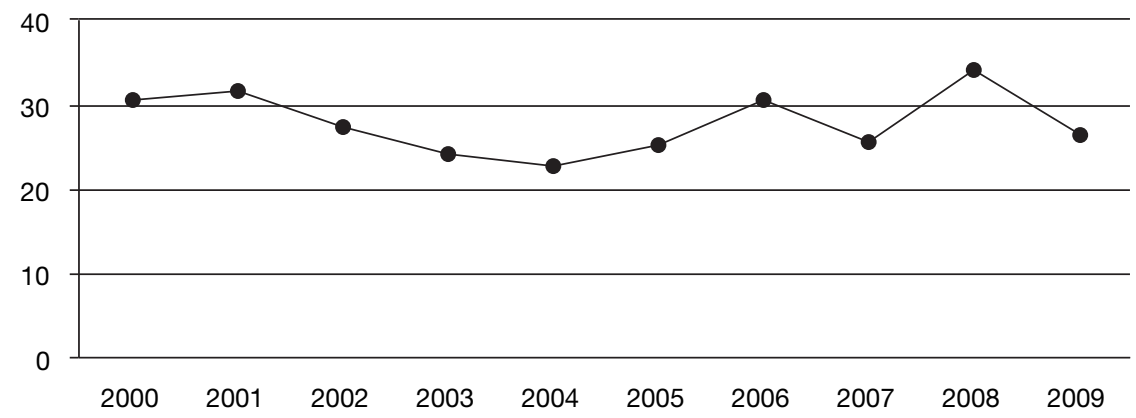

Source: Sozio-Ökonomisches Panel, waves 2000-2009 (n varies between 161 and 286); authors' calculations

old school students holding part-time jobs (Fig. 1). The time series reveals no clear rising or falling trend in the uptake of such jobs by 17-year-old school students. What it does show is relatively large variations between individual calendar years, but this may be due in part to the relatively small number of cases in the years concerned.

Our calculations for the year 2009 confirm the data from other German studies. A third of 13- to 17-year-olds are working. The proportion rises from $13 \%$ of the 13 -year-olds to $55 \%$ among 17 -year-olds (see Table 1)

According to the findings of the AID:A Survey, of these students with part-time jobs:

- $20 \%$ work only during school holidays

- $28 \%$ work only during school terms

- $52 \%$ work during both the school term and holidays

The data offer no evidence relating to age as a factor in this division between work during school holidays and during term time.

Table 1 relates the frequency of part-time jobs for school students to a number of separate characteristics. The figures are consistent with those from other countries in showing that the proportion of those pursuing a job while at school increases with age. ${ }^{5}$ There also seems to be a gender-specific effect, with more girls than boys taking jobs in the higher age groups.

The uptake of part-time jobs is also always dependent on general employment conditions. In regions and towns with relatively few employment opportunities there are also fewer part-time jobs to be had. It is relevant

5. Any consideration of the frequency of part-time jobs in Germany has to take into account the existence of regulations expressly designed for protection (Feil, 2003: 207). For example, children are not permitted to babysit. The intention is to protect them from excessively taxing roles, such as carrying babies. 
Table 1. Percentage of school students holding part-time jobs categorised according to various characteristics

\begin{tabular}{|c|c|c|c|c|c|c|c|c|c|c|c|c|c|}
\hline \multirow[b]{2}{*}{ Age } & \multicolumn{2}{|c|}{ Region } & \multicolumn{2}{|c|}{ Gender } & \multicolumn{2}{|c|}{ School } & \multicolumn{2}{|c|}{$\begin{array}{l}\text { Immigration } \\
\text { background }\end{array}$} & \multicolumn{2}{|c|}{$\begin{array}{l}\text { Household } \\
\text { income }\end{array}$} & \multicolumn{2}{|c|}{$\begin{array}{l}\text { Out-of-school } \\
\text { duties or } \\
\text { responsibilities }\end{array}$} & \multirow[b]{2}{*}{ Total } \\
\hline & $\begin{array}{l}\text { East } \\
\text { (294) }\end{array}$ & $\begin{array}{c}\text { West } \\
\text { (2229) }\end{array}$ & $\begin{array}{c}\text { Male } \\
\text { (1310) }\end{array}$ & $\begin{array}{c}\text { Female } \\
\text { (1283) }\end{array}$ & $\begin{array}{l}\text { Haupt- oder } \\
\text { Realschule, } \\
\text { i.e. less } \\
\text { academic } \\
\text { (741) }\end{array}$ & $\begin{array}{l}\text { Gymnasium, } \\
\text { i.e. more } \\
\text { academic } \\
(1392)\end{array}$ & $\begin{array}{c}\text { No } \\
\text { (2139) }\end{array}$ & $\begin{array}{c}\text { Yes } \\
(454)\end{array}$ & $\begin{array}{c}\text { Below } \\
\text { median } \\
(1596)\end{array}$ & $\begin{array}{l}\text { Above } \\
\text { median } \\
(806)\end{array}$ & $\begin{array}{l}\text { Yes } \\
\text { (720) }\end{array}$ & $\begin{array}{c}\text { No } \\
\text { (1873) }\end{array}$ & \\
\hline $13(564)$ & $5 \%$ & $14 \%$ & $13 \%$ & $13 \%$ & $14 \%$ & $12 \%$ & $13 \%$ & $14 \%$ & $13 \%$ & $12 \%$ & $10 \%$ & $22 \%$ & $13 \%$ \\
\hline $14(618)$ & $22 \%$ & $27 \%$ & $26 \%$ & $28 \%$ & $27 \%$ & $28 \%$ & $26 \%$ & $32 \%$ & $27 \%$ & $25 \%$ & $25 \%$ & $30 \%$ & $27 \%$ \\
\hline $15(570)$ & $26 \%$ & $34 \%$ & $33 \%$ & $35 \%$ & $32 \%$ & $37 \%$ & $36 \%$ & $20 \%$ & $32 \%$ & $36 \%$ & $30 \%$ & $41 \%$ & $34 \%$ \\
\hline $16(451)$ & $31 \%$ & $47 \%$ & $44 \%$ & $47 \%$ & $38 \%$ & $50 \%$ & $48 \%$ & $38 \%$ & $45 \%$ & $44 \%$ & $41 \%$ & $58 \%$ & $46 \%$ \\
\hline $17(390)$ & $47 \%$ & $56 \%$ & $48 \%$ & $63 \%$ & $44 \%$ & $59 \%$ & $55 \%$ & $57 \%$ & $55 \%$ & $57 \%$ & $54 \%$ & $59 \%$ & $55 \%$ \\
\hline
\end{tabular}

Source: AID:A 2009; number of cases in brackets; authors' calculations.

here that the East-West comparison shows that school students in West Germany are more likely at all ages to have jobs than those of the same age in East Germany.

If school student uptake of part-time jobs is viewed in the context of regional unemployment figures, multivariate analysis will show that the differing proportion of part-time jobs in East and West Germany is not entirely attributable to the differing labour market situations. It appears in fact to reflect a difference in tradition between East and West Germany with regard to the uptake of part-time jobs. There are indications that some of the work done in West Germany by younger students in the context of out-of-school jobs is carried out in East Germany by older ones. Evidence of this may be found in the age structure of those holding 'mini-jobs' in West and East Germany. Representation of the youngest age group as a fraction of all persons with a mini-job is lower in East Germany than in the West (author's calculations from BA [Federal Labour Agency] 2012a, 2012b). In East Germany it might be more frequently the case that part-time jobs/mini-jobs are given to persons otherwise excluded from the labour market for full-time employees.

The uptake of part-time jobs is unrelated to household income. Nor are there any discernible associations between part-time job and the level of education of the household of origin or clear relationship between part-time job and immigrant background. On one criterion only, the type of school attended, a difference emerges: from about age 14 onwards, students attending a Gymnasium are rather more likely to have a part-time job than those attending a Hauptschule or Realschule.

In the context of the newly compressed school syllabus, a much-repeated conjecture has it that there should scarcely be much time to spare in the routine school day for additional activities. On this issue, the analysis of our survey data shows the following. Young people take part-time jobs and involve 
Table 2. Logistic regression, dependent variable: part-time job ( $1=y e s / 0=$ no)

\begin{tabular}{lcc}
\hline & Exp $(\beta)$ & $\mathrm{p}$ \\
\hline Highest educational qualification in household & 1.04 & 0.165 \\
Age & 1.63 & 0.000 \\
Female (Male) & 1.05 & 0.676 \\
Household above median income (below median income) & 0.79 & 0.043 \\
Immigration background (no immigration background) & 0.97 & 0.841 \\
School grade [= mark] for German & 0.88 & 0.073 \\
Undertakes duties/responsibilities in club (no duties/ responsibilities) & 1.38 & 0.004 \\
Undertakes duties/responsibilities at school (no duties/ responsibilities) & 1.49 & 0.003 \\
Gymnasium (Hauptschule and Rea/schule) & 1.17 & 0.212 \\
East Germany (West Germany) & 0.66 & 0.048 \\
City/town > 20,000 inhabitants (Town/village < 20,000 inhabitants) & 0.94 & 0.632 \\
Unemployment rate in region of residence & 0.99 & 0.529 \\
Constant & 0.00 & 0.000 \\
\hline
\end{tabular}

In brackets: reference category; Hosmer-Lemeshow Test (Chi 12,159, df =8, $p=0.14$ ); Cox \& Snell R-square: 0.109; Nagelkerkes R-square: 0.151; percentage correctly predicted classification: $69.5 ; n=1941$

Source: AID:A 2009; authors' calculations.

themselves in other activities. ${ }^{6}$ This confirms that a degree of flexibility remains even in the context of the fully timetabled, routine school day. Furthermore, part-time jobs are evidently not impairing school attainment. According to our data, the improved "final school mark in German" is significantly better among the group with part-time jobs than among young people without them.

Having an out-of-school job forces those concerned to rationalise their time management. The findings of the 2009 volunteering survey point in the same direction. On the issue of planning leisure time, they indicate that subjective time awareness and the capacity for the structured use of opportunities as they occur are closely related to the level of education (TNS Infratest Sozialforschung, 2010: 198). The higher the level of education, the more positive the view that individual leisure time can be planned.

Logistic regression with the dependent variable 'part-time job held or not' confirms the results from studying the bivariate associations (Table 2). The differentiating factor that stands out from the rest is age in years: the proportion of those pursuing a job while at school increases with age. Gender, immigration background, type of school attended, highest educational qua-

6. The possibility cannot be excluded that some of the children and young people see the responsibilities and duties that they may have in clubs and associations as constituting a "part-time job", especially in cases where they may receive some small compensation (e.g. travel expenses) for outlay on their part. Depending on the amount of pocket money received, even small extra payments may represent a large fraction of the disposable budget. In the survey instrument, the question relating to earned money (part-time jobs) was located remotely from the questions relating to activities in clubs and associations, so that interference effects are likely to have been negligible. 
lification in household, town size and unemployment rate in the region have no significant impact. Other statistically significant factors besides age are the East versus West Germany distinction and the issue of voluntary commitment (acceptance of duties and responsibilities) both at and outside school (e.g. a youth club): school students in West Germany and young people who are involved in voluntary activities are more likely to have jobs than those in East Germany and those without voluntary commitment. While on a bivariate basis there are scarcely any perceptible differences between school students according to whether the household income lies above or below the median income, the multivariate model shows a higher probability of part-time jobs among students from lower-income households. In the multivariate model, the final school mark for German is significant only at the $10 \%$ level $(\mathrm{p}=0.073)$.

It is clear that part-time jobs taken by school students are not detrimental either to voluntary activities or to school attainment. ${ }^{7}$ In terms of the students' self-efficacy valuations, there is a significant and positive correlation with holding a part-time job (Welch-test: $\mathrm{T}=-6.078, \mathrm{df}=2784,7, \mathrm{p}<0.000) .{ }^{8}$ This suggests that part-time jobs can create a context in which young individuals are able to test and develop their capabilities in real-life conditions and appreciate the efficacy (effectiveness) of their actions first hand: their self-efficacy. Whether this is really the case, however, can be determined only by means of a longitudinal design, since it is conceivable that individuals who perceive themselves as self-effective are more likely to take up part-time jobs, in which case self-efficacy would be the determining factor behind taking a job as opposed to the consequence of holding one.

\section{School student budgets/spending money}

The survey of 17-year-old school students found that the most frequently cited motive for having a part-time job was 'to earn money', which accounted for $81 \%$ of the responses (authors' calculations from SOEP data, see section "Data basis and methodology"). A mere $15 \%$ of these 17 -year-olds stated that their motive for the job was interest in the work concerned. Part-time jobs are thus viewed by the young people themselves primarily from an earnings perspective, and less as an opportunity to learn and to acquire experience. This raises the question of how young people are placed financially, with and without parttime jobs. That will be the subject of the next section.

Pocket money, special allowances, money that they earn in their own right, and other income sources together constitute the budget available to young people to use as they wish. A survey question accordingly asked about the relevance of various sources of this spending money, producing the following picture: on average, 13 - to 17 -year-olds named 1.8 sources. The most frequently

7. In Germany, marks range from 1 (very good) to 6 (unsatisfactory).

8. This link is also observed in a multivariate model with the dependent variable "self-efficacy" (see Appendix) 
Table 3. Size of monthly disposable budget of school students (figures in euros)

\begin{tabular}{|c|c|c|c|c|c|c|c|c|c|c|c|}
\hline \multirow[b]{2}{*}{ Age } & \multicolumn{2}{|c|}{ Region } & \multicolumn{2}{|c|}{ Gender } & \multicolumn{2}{|c|}{ School } & \multicolumn{2}{|c|}{$\begin{array}{l}\text { Immigration } \\
\text { Background }\end{array}$} & \multicolumn{2}{|c|}{$\begin{array}{l}\text { Household } \\
\text { income }\end{array}$} & \multirow[b]{2}{*}{ Tota } \\
\hline & $\begin{array}{l}\text { East } \\
\text { (319) }\end{array}$ & $\begin{array}{l}\text { West } \\
\text { (2444) }\end{array}$ & $\begin{array}{c}\text { Male } \\
\text { (1411) }\end{array}$ & $\begin{array}{c}\text { Female } \\
(1352)\end{array}$ & $\begin{array}{c}\text { Realschule } \\
\text { i.e. less } \\
\text { academic } \\
\text { (716) }\end{array}$ & $\begin{array}{l}\text { Gymnasium, } \\
\text { i.e. more } \\
\text { academic } \\
(1366)\end{array}$ & $\begin{array}{c}\text { No } \\
\text { (2294) }\end{array}$ & $\begin{array}{c}\text { Yes } \\
(469)\end{array}$ & $\begin{array}{c}\text { Below } \\
\text { median } \\
(1726)\end{array}$ & $\begin{array}{c}\text { Above } \\
\text { median } \\
(854)\end{array}$ & \\
\hline $13(552)$ & 60 & 39 & 43 & 39 & 28 & 54 & 42 & 36 & 37 & 37 & 41 \\
\hline $14(602)$ & 38 & 46 & 45 & 45 & 47 & 45 & 45 & 46 & 44 & 50 & 45 \\
\hline $15(564)$ & 57 & 56 & 60 & 52 & 49 & 58 & 57 & 49 & 53 & 54 & 56 \\
\hline $16(512)$ & 80 & 105 & 104 & 102 & 66 & 95 & 105 & 92 & 87 & 105 & 103 \\
\hline $17(533)$ & 164 & 145 & 151 & 143 & 81 & 91 & 150 & 134 & 146 & 157 & 147 \\
\hline
\end{tabular}

Source: AID:A 2009; number of cases in brackets; authors' calculations.

named were parents (91\%) followed a long way behind by grandparents and other relatives ( $42 \%)$, personal job earnings ( $40 \%$ ), and other income sources $(6 \%)$. It may be assumed, and should be taken into account, that some of the young people benefit, over and above their standing disposable budget, from extra cash made available to them to meet particular contingencies, e.g. an unexpectedly large mobile phone bill, a trip, or an expensive but desirable purchase.

In view of the strong correlation with age, Table 3 is subdivided into groups by age. The reported budget figures rise in line with age. From age 16 onwards, the disposable budget rises very appreciably. This may well mark the point at which independent cost-involving activities (e.g. "going out") become important to young people. Another development reflected in the figures at this point is that the start of part-time work at 16 or 17 will also considerably increase the disposable budget.

The separate figures for East and West Germany provide no evidence that school students in the two areas have different amounts of disposable cash even though the distribution of part-time jobs is unequal. Of the listed characteristics of individual students surveyed, gender, immigration background, and school type has no bearing on the size of the disposable budget.

Part-time jobs undoubtedly influence the disposable budget. This can be seen in Figure 2, which shows budgets for students with and without jobs. Except in the case of 14-year-olds, the budgets of school students with jobs are appreciably larger than those of their contemporaries without them. In the case of 16- and 17-year-olds the difference is substantial. Earlier, presumably, it will have been a matter of minor side earnings that increase the disposable budget only slightly. It is clear that part-time jobs open up a new scope for young people's individual consumer preferences.

A multivariate linear regression (OLS) analysing the factors that influence budget size and taking due account of the variable representing the holding of a job further confirms most of the links observed in the bivariate analysis 
Figure 2. School student budget by age and job/no job category

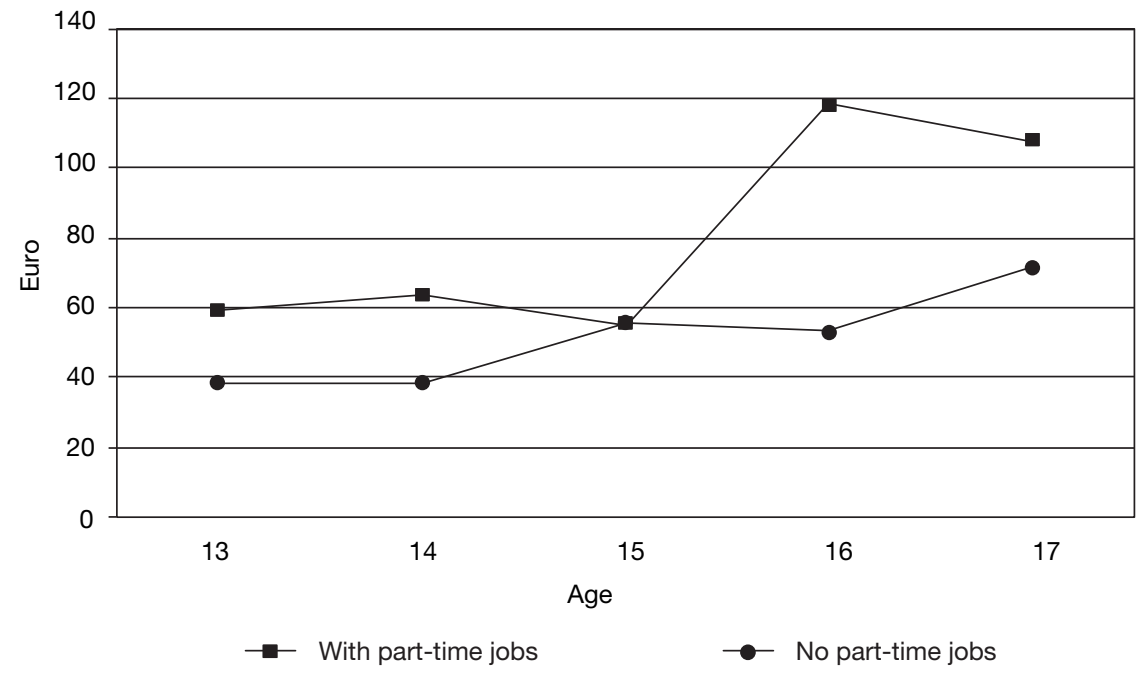

Source: AID:A 2009; author's calculations.

Table 4. Linear regression, dependent variable: Disposable budget for school students

\begin{tabular}{lrrc}
\hline & \multicolumn{1}{c}{ B } & \multicolumn{1}{c}{ Beta } & \multicolumn{1}{c}{$\mathrm{p}$} \\
\hline Part-time job (no part-time job) & 23.937 & 0.129 & 0.000 \\
Highest educational qualification in household & -2.252 & -0.050 & 0.055 \\
Age & 9.647 & 0.148 & 0.000 \\
Female (Male) & 0.591 & 0.003 & 0.880 \\
Household above median income (below median income) & 8.630 & 0.047 & 0.053 \\
Immigration background (no immigration background) & 3.888 & 0.017 & 0.464 \\
Gymnasium (Hauptschule and Realschule) & 7.587 & 0.041 & 0.110 \\
East Germany (West Germany) & 4.361 & 0.015 & 0.499 \\
City/town > 20,000 inhabitants (Town/village < 20,000 inhabitants) & 5.646 & 0.030 & 0.178 \\
Constant & -112.596 & & 0.000 \\
\hline
\end{tabular}

In brackets: reference category; Corrected R-square: 0.052; $n=1929$

Source: AID:A 2009; authors' calculations.

(Table 4). Age is the most important factor, closely followed by the part-time job. A higher household education level corresponds to lower budgets for young people $(\mathrm{p}=0.055)$. Children, too, and young people from low-income households have smaller budgets at their disposal $(\mathrm{p}=0.053)$. All the remaining factors prove to have a statistically insignificant effect. Thus, the salient point that emerges is the fact that children and young people from lower-income households are evidently not able to increase their budget to the levels enjo- 
yed by young people from higher-income households, even with the help of a part-time job.

\section{Commonalities and Differences: the position in Germany and in the other countries}

Study of the part-time work situation in the various individual countries permits identifying commonalities and differences, notwithstanding differences in survey procedures. In all the countries concerned, growing years are influenced to considerable extent by part-time work. Most apparent at first sight are the major differences in terms of the proportion of young people who choose to take part-time jobs; a practice that is clearly more widespread in Englishspeaking countries than in Germany. As mentioned at the beginning of this paper, this could be related to the differing perceptions of the youth phase: on the one hand as a moratorium and on the other as a transition. Where youth is more firmly perceived as a transition period, as is the case in the Englishspeaking world, it seems only logical that young people are more routinely encouraged to enter the world of employment relatively early with a view to building up the needful practical experience.

The supply of jobs depends largely on the structure of society in the country concerned. The pattern of consumption and service provision within society varies between countries. This is reflected inter alia in perceptible differences in the supply of part-time jobs. Provision of services, for example, is significantly more important in relative terms in the US than, say, in Germany. It is thus natural that reports from the US speak more frequently of jobs in the hospitality and retail sectors.

It is not only in Germany that the number of young people in work rises with age. One of the reasons for this seems to be that as individuals grow older they need increasing amounts of money. For the young of all countries, money is the principal motive for taking on part-time work; interest in the content of the work is universally much less often mentioned. Even so, a parttime job may well be regarded as a setting for an informal learning process. Reservations with regard to part-time jobs are also similar across the various countries. As far as formal learning at school is concerned, Germany is like other countries in displaying no correlation between having a part-time job and school attainment.

In the English-speaking countries there is a stronger focus on ethnicity. The research goes beyond the binary ethnic origin category (immigrant background or not) to which German studies confine themselves, in that it distinguishes a number of different ethnicities - not always the same ones (Payne, 2001: 36; BLS, 2005). The survey findings in countries where members of ethnic minorities do less part-time work are probably attributable to the largely informal control exercised over access to the part-time jobs market. This system begets specialised forms of integration and exclusion. The findings also show that in some countries gender is not a factor at all, while in other countries, 
by contrast, preparedness to take part-time jobs depends on the emergence of gender identity.

The research findings drawn from other countries were supplemented in the present study by a regional comparison which seeks to identify the relevance of region to the employment market. Although more than 20 years have passed since reunification, East and West Germany are still by no means on an equal economic footing. Both labour markets are highly flexible. Part-time jobs, as well as micro- and mini-jobs are frequently offered. In socio-economically disadvantaged regions such as East Germany, the part-time employed as well as school students and pensioners are more likely to compete for part-time and side jobs. This is an indication that attention should be paid to regional differences in the distribution of part-time jobs and to their implications for earnings potential.

Our approach is again wider than that of other studies in that we include the topic of consumption. The focus is not simply on the bald statistics of income from part-time work, but on their relevance to the overall personal budget. Income from part-time work is almost always part of the overall budget (pocket money and personal income). Moreover, the information is in all cases viewed in relation to the financial position of the parental household. This is important, because for young people the point of having a job is to exercise their consumer choices independently of any financial support from the family.

\section{Conclusion: Job and School - Living in Parallel Worlds}

From an overall view, the ubiquity of part-time jobs among school students, associated dangers, and positive development potential in terms of training and education for young people are far from being matched by the quantity of empirically tested research results available to date.

Most studies can be said to provide a perspective on the topic at the superficial level, but more penetrating analyses and conclusions run into difficulty. Often there is insufficient information on the nature of the activities, on the number of hours being spent on out-of-school jobs, on the age at which the young people concerned have taken up part-time work, and on operationalisations for possible competence gains.

However, some of the assumptions about today's young people can be revised on the basis of current data. It has been assumed that the youth phase has become appreciably longer, and the formation of employment contacts correspondingly delayed. It now seems this is not the case. Up until the 1970s, the standard life history of a young person in Germany meant that he or she would begin a career apprenticeship at the age of 15 or 16, therewith entering the labour market and earning a wage for the first time. Today, the average age for beginning professional training is 19.4 years (Uhly, 2009: 157). However, we know that a good third of all school students have jobs at least part of the time. For these individuals, school attendance and work are not successive events, but run parallel (Tully, 2004a). As for the assumption that 
youth is a period of continuous peer-orientation, how convincing does it look today? Over and above the pecuniary rewards of work (i.e. the attainment of a personal income), there can be little doubt that breaching the principle of peer-orientation at this age also matters. On getting a job, one enters a mixedage environment. The way people communicate is different; new rules and expectations have to be learnt.

\section{The future of part-time jobs}

The attempt to describe part-time jobs as a subset of employment in general has proved unsuccessful: they are configured differently, and their motivation is different. This is the reason for the lack of success in characterising the scope, duration, and quality of the employment conditions actually obtained. Parttime jobs for school students are envisaged by both sides - the young people accepting them, and the employer - as short-term. A comparison of part-time jobs and the professional career reveals these differences. In the former, the focus is on gainful activity for the sake of earning, and identification with the work itself is low. The aim is to be able to live in detachment from other areas of life (in parallel worlds). Qualifications are acquired through "on-the-job training", with frequent job changes being the norm. In complete contrast, a professional career, whether manual or white collar, demands specific preparatory training, is predicated on relatively long-term job tenure, and as a rule requires specific qualifications. It involves strong identification with the duties to be undertaken and acceptance of professional standards (quality norms, ethical principles, etc.). The gainful activity here supports the employee's subsistence long-term. The nature of the work also determines the social status that corresponds to the particular professional activity.

In Germany, part-time jobs for school students belong to a grey area between the recognised employment market and the various informal types of employment. This tends to suggest that the principal occupation of young people in part-time jobs in Germany is more often in the area of private assistance and services. This was probably not the case 20-30 years ago. There were positions described as Ferienjobs (holiday jobs) that consisted of temporary stand-in work during regular employees' holidays or sick leave. Work of this kind is now fairly uncommon. In the first place, such employment fluctuations have latterly become the business domain of professional employment agencies specialising in hourly-paid temporary positions. Also, labour is now organised for maximum flexibility as reflected in employment types such as project work, part-time work, temporary positions, and mini-jobs. A further factor is that the overall proportion of unskilled posts has been declining (Pfeiffer and Kaiser, 2009: 17). In the future, it seems likely that demand from this quarter for the services of school students will decline. In the work types with which they are associated, such as house-to-house distribution of advertising material, competition for jobs has already increased (e.g. from the unemployed, people on benefits, people on inadequate pensions, mini-job holders, and digitalisation of 
advertising replacing flier distribution). One likely demographic development will be of relevance to the student job market: the growing proportion of older people in the population could lead to an increase in demand for personal services (shopping, gardening, and the like).

For the time being, at least, Germany is experiencing a rising demand for jobs hitherto taken by school students, but no increase in vacancies. The factors contributing to this are economic distress among pensioners, the growing demand by university students for such jobs (the numbers working while studying at a tertiary institution rose from $60 \%$ in 2006 to $65 \%$ in 2009; Isserstedt et al., 2010: 194). Absolute numbers of university students are also on the rise (by $27 \%$ in the last ten years; figures from the Statistisches Bundesamt [Federal Office of Statistics], 2012). The number of children and young people growing up in financially precarious family circumstances is also increasing (from 16\% of children under 15 in 2000, the figure rose to 26\% in 2006; Hübenthal, 2009: 10). All this suggests that a greater number of young people are having to look to supplementary funding in order to support themselves while still at school. Research on the issue, as has already been shown, is still in the early stages; a fact that contrasts starkly with the visibly advancing invasion of young people's everyday lives by economic interests. Active market research in this area continues unabated, while youth research to date has very largely ignored the commercialisation of its subjects' lives. This is no less true with regard to the sources of the funds that young people have at their disposal.

\section{References}

Abhayaratna, Joanna; Andrews, Les; Nuch, Hudan and Podbury, Troy (2008). Part Time Employment: the Australian Experience, Staff Working Paper, Productivity Commission.

Alt, Christian; Gille, Martina and Prein, Gerald (2011). "Alltagswelten erforschen: AID:A. Forschungsziele, Methodik und Umsetzung der DJI-Surveyforschung” [Investigating Everyday Life. Research Goals, Methods and Implementation of the German Youth Institute Survey]. Impulse, 92/93, 31-35.

Beicht, Ursula and Krewerth, Andreas (2010). "Geld spielt eine Rolle! Sind Auszubildende mit ihrer Vergütung zufrieden?” [Money does matter! Are Apprentices satisfied with their pay?]. BIBB-Report, 14/10.

Bundesagentur für ARBeIt (BA) (2012a). Arbeitsmarkt in Zablen. Beschäftigungsstatistik. Geringfügig Beschäftigte nach Altersgruppen Land Westdeutschland [Labor Market in Figures. Employment Figures. Marginal Employment According to Age in West Germany]. Accessed November 20. 2013

$<$ http://statistik.arbeitsagentur.de/nn_31962/SiteGlobals/Forms/Rubrikensuche/Rubrikensuche_Form.html?view=processForm\&resourceId=210368\&in put_$=\&$ pageLocale $=$ de\&topicId $=31690 \&$ year_month=aktuell \&year_month. GROUP=1\&search $=$ Suchen $>$.

Bundesagentur für ArbeIt (BA) (2012b) Arbeitsmarkt in Zablen. Beschäftigungsstatistik. Geringfiugig Beschäftigte nach Altersgruppen Land Ostdeutschland [Labor Market in Figures. Employment Figures. Marginal Employment According to Age in East Germany]. Accessed November 20. 2013 
<http://statistik.arbeitsagentur.de/nn_31962/SiteGlobals/Forms/Rubrikensuche/Rubrikensuche_Form.html?view=processForm\&resourceId=210368\&in put_=\&pageLocale $=$ de\&topicId=31690\&year_month=aktuell\&year_month. GROUP $=1$ \&search $=$ Suchen $>$.

BLS (Bureau of Labor Statistics) (2004). "Employment of Teenagers during the School Year and Summer”. BLS News, February 18,. USDL 04-217. Washington, D.C.: United States Department of Labor.

BLS (Bureau of Labor Statistics) (2005). "Work Activity of High School Students: Data from the National Longitudinal Survey of Youth 1997”. BLS News, April 27. USDL 05-732. Washington, D.C.: United States Department of Labor.

Eckersley, Richard (1992). Youth and the Challenge to Change. Carlton South: Australia's Commission for the Future.

Entwisle, Doris R.; Alexander, Karl L.; Steffel Olsen, Linda and Ross, Karen (1999). "Paid Work in Early Adolescence: Developmental and Ethnic Patterns". The Journal of Early Adolescence, 19(3), 363-388. <http://dx.doi.org/10.1177/0272431699019003004>

Frederiksen, Lisa (1999). "Child and Youth Employment in Denmark. Comments on Children's Work from their Own Perspective”. Childhood, 6(1), 101-112. <http://dx.doi.org/10.1177/0907568299006001008>

Frick, Joachim R.; Groh-Samberg, Olaf; Schupp, Jürgen and Spiess, C. Katharina (2008). "25 Wellen Sozio-Oekonomisches Panel" [25 Waves of the German Socio-Economic Panel (SOEP)]. Vierteljahreshefte zur Wirtschaftsforschung 3. Berlin: Deutsches Institut für Wirtschaftsforschung.

Furlong, Andy; Woodman, Dan and Wyn, Johanna (2011). "Changing times, changing perspectives. Reconciling 'transition' and 'cultural' Perspectives on youth and young adulthood”. Journal of Sociology, 47(4), 355-370. <http://dx.doi.org/10.1177/1440783311420787>

Howieson, Cathy; McKechnie, Jim and Semple, Sheila (2006). The Nature and Implications of the Part-time Employment of Secondary School Pupils. Scottish Executive Social Research.

Howieson, Cathy; McKechnie, Jim; Hobbs, Sandy and Semple, Sheila (2012a). "New Perspectives on School Students' Part-time Work". Sociology, 46(2), 322-338. <http://dx.doi.org/10.1177/0038038511419183>

Howieson, Cathy; McKechnie, Jim and Semple, Sheila (2012b). "Working Pupils: Challenges and Potential". Journal of Education and Work, 25(4), 423-442. <http://dx.doi.org/10.1080/13639080.2012.708723>

Hübenthal, Maksim (2009). Kinderarmut in Deutschland. Empirische Befunde, kinderpolitische Akteure und gesellschaftspolitische Handlungsstrategien [Child Poverty in Germany. Empirical Findings, Political Actors and Policies]. München: Deutsches Jugendinstitut.

Isserstedt, Wolfgang; Middendorff, Elke; Kandulla, Maren and Lesczensky, Michael (2010). Die wirtschaftliche und soziale Lage der Studierenden in der Bundesrepublik Deutschland 2009. 19. Sozialerhebung des Deutschen Studierendenwerks durchgeführt durch HIS Hochschul-Informations-System [The Economic and Social Situation of Students in Germany in 2009. 19th Social Inquiry of the German Studierendenwerk executed by HIS]. Berlin: Bundesministerium für Bildung und Forschung.

LeE, MooSung and Ju, Eunsu (2010). "Effects of Part-time Work on Adolescent Development in Korea". Procedia Social and Behavioral Sciences, 2, 3226-3230. <http://dx.doi.org/10.1016/j.sbspro.2010.03.492> 
Leven, Ingo; Quenzel, Gudrun and Hurrelmann, Klaus (2010). "Familie, Schule, Freizeit: Kontinuitäten im Wandel" [Family, School, and Leisure Time: Continuities in Change]. In: Shell Deutschland Holding (ed.). Jugend 2010. Eine pragmatische Generation behauptet sich. Frankfurt a.M.: Fischer Taschenbuch Verlag, 53-128.

Luhmann, Niklas (2004). Schriften zur Pädagogik [Writings on Pedagogy]. Frankfurt a. M.: Suhrkamp.

Marsh, Herbert W. and Kleitman, Sabina (2005). "Consequences of Employment during High School: Character Building, Subversion of Academic Goals, or a Threshold?" American Educational Research Journal, 42(2), 331-369. <http://dx.doi.org/10.3102/00028312042002331>

McCoy, Selina and Sмyтн, Emer (2007). "So Much to Do, So Little Time: Parttime Employment among Secondary Students in Ireland". Work, Employment and Society, 21(2), 227-246. <http://dx.doi.org/10.1177/0950017007076630>

Mortimer, Jeylan T. and Larson, Reed W. (ed.) (2002) "The Changing Adolescent Experience". Cambridge: University Press. <http://dx.doi.org/10.1017/CBO9780511613913>

NSW Commission for Children and Young People (2005). Children at Work. Surry Hills: NSW Commission for Children and Young People.

Patton, Wendy and Smith, Erica (2010). "Part-time Work of School Students: Impact on Employability, Employment Outcomes and Career Development". Australian Journal of Career Development, 19(1), 54-62. <http://dx.doi.org/10.1177/103841621001900110>

Payne, Joane (2001). Post-16 Students and Part-Time Jobs: Patterns and Effects. A Report Based on the England and Wales Youth Cohort Study. DfES Research Report No 323.

Pfeiffer, Iris and Kaiser, Simone (2009). Auswirkungen von demographischen Entwicklungen auf die berufliche Ausbildung [Consequences of Demographic Trends on Vocational Training]. Berlin/Bonn: Bundesministerium für Bildung und Forschung.

Shell Deutschland Holding (1992). Jugend 1992 [Youth 1992]. Frankfurt: Fischer.

Shell Deutschland Holding (2002). Jugend 2002 [Youth 2002]. Frankfurt: Fischer.

Shell Deutschland Holding (2006). Jugend 2006 [Youth 2006]. Frankfurt: Fischer.

Shell Deutschland Holding (2010). Jugend 2010 [Youth 2010]. Frankfurt: Fischer.

Staff, Jeremy; Schulenberg, John E. and Bachman, Jerald G. (2010). "Adolescent Work Intensity, School Performance, and Academic Engagement." Sociology of Education, 83(3), 183-200. <http://dx.doi.org/10.1177/0038040710374585>

Statistisches Bundesamt (2012). Studierende [Students]. Accessed November 22. <https://www.destatis.de/DE/ZahlenFakten/Indikatoren/LangeReihen/Bildung/ lrbil01.html>.

TNS Infratest SozIALForschung (2010). Hauptbericht des Freiwilligensurveys 2009. Zivilgesellschaft, soziales Kapital und freiwilliges Engagement in Deutschland 1999 $-2004-2009$ [Findings from the Survey on Voluntarism. Civil Society, Social Capital and Voluntarism in Germany 1994-2004-2009]. München: TNS Infratest Sozialforschung.

Tanner, Jennifer L. and Arnett, Jeffrey J. (2009). "The Emergence of 'Emerging Adulthood'. The New Life Stage between Adolescence and Young Adulthood”. In: 
Andy Furlong (ed.). Handbook of Youth and Young Adulthood. New Perspectives and Agendas. New York: Routledge, 39-45.

Tully, Claus J. (2004a). "Schule und Job. Vom Nacheinander zum Nebeneinander" [School and Job. From Serial to Parallel]. Diskurs, 14(1), 54-63.

Tully, Claus J. (2004b). “Arbeitsweltkontakte von Schülerinnen und Schülern an allgemeinbildenden Schulen" [Contacts of School Students with the Working Environment]. Zeitschrift für Soziologie der Erziehung und Sozialisation, 24 (4), 408-430.

Tully Claus J.; Krug, Wolfgang and Sander, Ekkehard (2008). “Common Differences: Youth Research in Europe. An Analysis Based on Published English and Spanish Journal Articles". Papers, 90, 105-126.

Tully, Claus J.; Krug, Wolfgang and Wienefoet, Verena (2011). "Jugendkonsum in globalen Handlungsbezügen" [Youth Consumption in Global Contexts]. Zep: Zeitschrift für internationale Bildungsforschung und Entwicklungspädagogik, 34(4), 13-19.

Uhry, Alexandra (2009). “Ausbildungsbeteiligung der Jugendlichen” [Apprenticeships among Youth]. In: Bundesinstitut für Berufsbildung (ed.). Datenreport zum Bildungsbericht 2009. Informationen und Analysen zur Entwicklung der beruflichen Bildung. Bonn: Bundesinstitut für Berufsbildung, 156-163.

Windau, Janice and Meyer, Samuel (2005). "Occupational injuries among young workers”. Monthly Labor Review, 10/2005, 11-23.

Wray-Lake, Laura; Syvertsen, Amy K.; Briddel, Laine; Osgood, D. Wayne and Flanagan, Canstance A. (2011). "Exploring the Changing Meaning of Work for American High School Seniors From 1976 to 2005". Youth \& Society, 43(3), $1110-1135$.

<http://dx.doi.org/10.1177/0044118X10381367>

\section{Appendix}

Table 5. Linear regression, dependent variable: disposable budget for school students

\begin{tabular}{lrrr}
\hline & B & Beta & $p$ \\
\hline Part-time job (no part-time job) & 0.171 & 0.047 & 0.046 \\
Highest educational qualification in household & -0.038 & -0.043 & 0.079 \\
Age & 0.129 & 0.101 & 0.000 \\
Household above median income (below median income) & 0.327 & 0.092 & 0.000 \\
East Germany (West Germany) & 0.251 & 0.045 & 0.044 \\
City/town > 20,000 inhabitants (Town/village <20,000 inhabitants) & 0.199 & 0.055 & 0.015 \\
Constant & 12.555 & & 0.000 \\
\hline
\end{tabular}

In brackets: reference category; method = backward, excluded variables: school type, sex and (no) migration background; Corrected R-square: 0.023; $n=1929$.

Source: AID:A 2009; authors' calculations. 